\title{
Многослойные материалы для теплозащиты
}

\section{Thermal protection multilayer materials}

\section{Н. С. Лукичева}

Объединение юридических лиц

«Союз производителей композитов», г. Москва, Россия

\section{В. В. Марценюк, А. А. Лысенко}

Санкт-Петербургский государственный университет промышленных технологий и дизайна, г. Санкт-Петербург, Россия

\section{А. С. Беспалов, А. Я. Баринов}

ФГУП «ВИАМ» ГНЦ РФ, г. Москва, Россия

\author{
N. S. Lukicheva \\ Union of Composites Manufacturers, \\ Moscow, Russia
}

V. V. Martsenyuk, A. A. Lysenko

Saint-Petersburg State University of Industrial Technologies and Design, S-Petersburg, Russia

\section{A. S. Bespalov, D. Ya. Barinov}

FSUE «VIAM» SCR RF, Moscow, Russia

Поступила в редакцию 20.12.2019, принята к печати 06.03.2020.

\section{Абстракт}

Разработаны несколько видов многослойных углерод-углеродных и углерод-полимерных композиционных материалов различной структуры для защиты от высоких и низких температур. Исследованы их теплозащитные и механические свойства. Показана эффективность применения многослойных углеродных композиционных материалов и представлены области их применения. Полученные углерод-углеродные многослойные образцы в результате высокотемпературных методов обработки обладают высокой термостойкостью, формоустойчивостью и коэффициентом теплопроводности 0,068 Вт/м.К. Они могут использоваться для термоизоляции в установках и процессах, протекающих при сверхвысоких температурах (до $2500^{\circ} \mathrm{C}$ ) в инертной среде.

Образцы многослойных материалов, полученные «низкотемпературным методом», могут рассматриваться в качестве перспективных материалов в качестве новых видов теплозащиты в интервале температур от -60 до $+150^{\circ} \mathrm{C}$, например, для решения задач термоизоляции оборудования, зданий и сооружений в условиях низких температур Арктики, Крайнего Севера и Антарктики.

\section{Abstract}

Several types of multilayer carbon-carbon and carbon-polymer composite materials of various structures were developed as thermal isolation materials to be used at high and low temperatures. There were studied thermal conductivity and mechanical properties of the composites. The effectiveness of the usage of multilayer carbon composite materials was shown and various fields of the application. The composites obtained via high-temperature processing methods have high heat resistance, shape stability, they have thermal conductivity of $0.068 \mathrm{~W} / \mathrm{m} \cdot \mathrm{K}$. They can be used for thermal insulation at ultra-high temperatures, up to $2500^{\circ} \mathrm{C}$ in an inert atmosphere. The composites obtained via low-temperature processing methods are to be prospective materials for thermal isolation at temperatures from -60 to $+150^{\circ} \mathrm{C}$. Their usage in equipment, buildings, and infrastructures at low temperatures in the Arctic, Far North and Antarctic can be very useful.

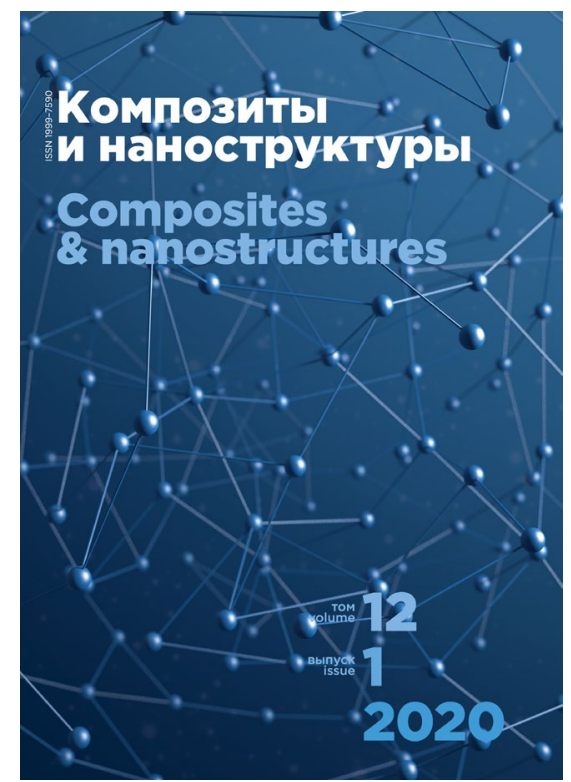

